\title{
Yhwh, the Goddess and Evil: Is 'monotheism' an adequate concept to describe the Hebrew Bible's discourses about the God of Israel?
}

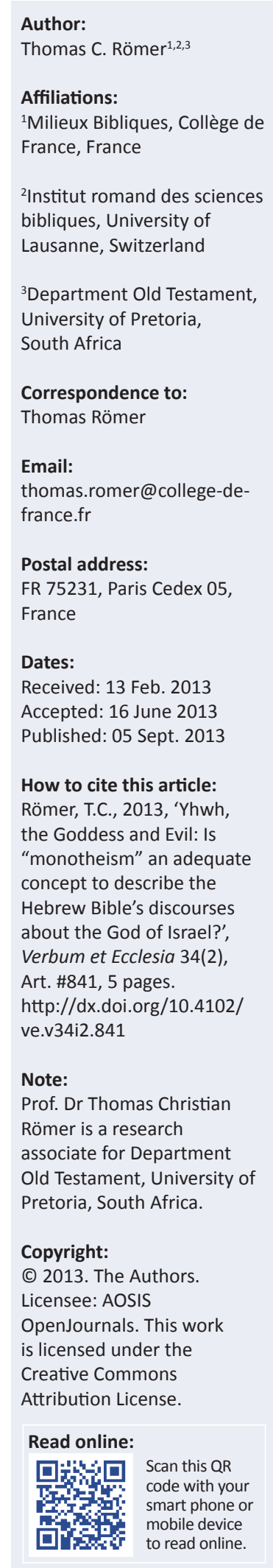

The concept of 'monotheism' has become a matter of debate in Hebrew Bible scholarship. This article investigates whether the concept should still be used, starting with Second Isaiah, who in the early Persian period elaborated a discourse that presented Yhwh as the only god. Therefore he had to integrate into this deity functions traditionally attributed to goddesses and to demons or evil gods. However, this attempt did not succeed. The goddess, whose elimination is probably reflected in Zechariah 5, returned in a certain way through the personification of Wisdom in Proverbs 8, and the 'dark sides' of the gods were materialised in the figure of Satan, who experienced an impressive career in the following centuries. The question of evil is not resolved in the Hebrew Bible. Some texts admit the autonomy of evil, whereas Isaiah 45 claims that Yhwh himself is at the origin of evil. This diversity makes it difficult to characterise the Hebrew Bible as the result of a straightforward evolution from polytheism to monotheism.

\section{Introduction}

In a recent article, Jurie le Roux has emphasised the fact that in Biblical and historical research the 'good' question is as important as the answer (Le Roux 2009). It is my pleasure to offer to my revered colleague and dear friend the following preliminary observations in which I will ask whether we still should continue to use the term 'monotheism' when speaking of the theological discourses of the Hebrew Bible. This article will not deal with the general debate about monotheism, which is a major issue in current Biblical and theological investigations (see Ahn 1993; MacDonald 2003 and Römer 2010). As Stolz (1996) has demonstrated, the philosophical or theological concept of monotheism is a modern invention from the time of enlightenment. It has been used since then in order to prove the superiority of the monotheistic religion in regard to paganism and polytheism. However, a strict monotheism is not such an easy thing. If there is only one god, is he responsible for evil? And how can one enter in contact with this transcendent god? It is not astonishing that the three major monotheistic religions, Judaism, Christianity and Islam, all allow for some kind of dualism (by admitting a 'Satan') and also for 'angels', intermediaries between God and mankind.

This article focuses on some developments and problems that occurred during the time in which the traditional Hebrew religion changed into Judaism and monotheism.

Since De Wette, Colenso and Wellhausen, most scholars would agree on the idea that 'Judaism' did not rise earlier than the Persian period - maybe even much later. It is clear, however, that the destruction of Judah and Jerusalem in $587 \mathrm{BCE}$, as well as the reactions to that crisis in writings from the Persian period, constitute a major caesura (Le Roux 2008). During the times of the Israelite and Judean monarchies, the cult of Yhwh as the national deity did not differ much from the religious conceptions of Israel's and Judah's neighbours in the Levant. The socalled Josianic reform may have introduced some changes by trying to establish some kind of monolatrism, probably without much success (Uehlinger 1995). The abolition of Assyrian cultic symbols in the Jerusalem temple was not necessarily a sign of an anti-Assyrian insurrection; it might simply reflect the loss of Assyrian power in Syria and Palestine in the late 7th century, as the idea of centralisation may simply reflect the situation of a quite truncated state of Judah in which Jerusalem remained the only important city and its temple the only remaining sanctuary. The Judean religion, during the time of the monarchy, was centred on a national god who had priority over other gods and whose temple (and perhaps statue) was the visible sign of his presence amongst his people. ${ }^{1}$ The mediators of this presence were the king and, by delegation, the priests. There is also clear biblical and extra-biblical evidence that until the Josianic reform Yhwh was associated with a goddess, Asherah, whose title may have been 'the Queen of Heaven' 
(Koch 1988). Apparently, this title could be used for different goddesses: Ishtar in Mesopotamia, Astarte, Anat and Asherah in the Levant, Hera in Greek mythology, and Mary in Catholic religion. ${ }^{2}$

The collapse of Judah was apparently explained by parts of the population as a punishment of the Queen of Heaven whose cult had been neglected by the Judeans. Jeremiah portrays the Judeans that have fled to Egypt complaining:

But from the time we stopped making incense offerings to the queen of heaven and pouring out libations to her, we have lacked everything and have perished by the sword and by famine. (Jr 44:18)

Here the destruction of Jerusalem and the difficult post-587 BCE situation is seen as having been provoked by the Queen of Heaven, angry that she was not worshipped any more. The idea that the disaster is happening because a deity becomes angry with his people and abandons it is well attested in the Ancient Near East. ${ }^{3}$

\section{Yhwh, commander of the foreign nations}

The idea that the Babylonian gods would have defeated Yhwh apparently offered, for parts of the Judean population, a possible explanation for the events of 587 BCE. DeuteroIsaiah's affirmation that 'Yhwh's arm is not too short to save' (Is 50:2; cf. Is 59:1) can be understood as a reaction against those who were not convinced any more by Yhwh's power. And the Deuteronomistic authors of 2 Kings 24-25 insist on the fact that the Babylonians who destroyed Jerusalem had been sent by Yhwh himself in order to strike his people:

Yhwh sent against him bands of the Chaldeans, bands of the Arameans, bands of the Moabites, and bands of the Ammonites; he sent them against Judah to destroy it, according to the word of Yhwh that he spoke by his servants the prophets ... This happened to Jerusalem and Judah because of the anger of Yhwh and he threw them away from his face. (2 Ki 24:2, 20a)

The idea that Yhwh controlled the Babylonians, who became his tool in order to carry out his judgment, was taken over and elaborated in the book of Second Isaiah. This scroll, which was conceived independently from Proto-Isaiah, ${ }^{4}$ also understands the fall of Jerusalem as a sign of divine wrath, which led Yhwh to hide himself and not to intervene in favour of his people: 'I was angry with my people, I profaned my heritage' (Is 47:6). But the author of this book, or a later

2.For an overview, see Schmitz (1992). It is not necessary to follow Ackerman $(1989: 116-117)$ and to postulate that the Queen of Heaven in Jeremiah 44 was a separate syncretistic deity.

3.For instance, in the Mesha stela, the poem of Erra, and also in the Harran inscription: 'Sîn, the king of all gods, became angry with his city and his temple, and went up to heaven and the city and the people became desolate', (Pritchard 1955:560-562) and is applied to Yhwh in the Deuteronomistic history, where the fall of Samaria and the destruction of Jerusalem appear as Yhwh's punishment of the kings who did not worship him adequately. Another way to explain military defeats is to imagine that the God of the vanquishers has defeated the god(s) defeats is to imagies. This is a typical motive of Assyrian propasanda, which is in the Hebrew Bible reflected in 2 Kings 18:31-35.

4.By Levites, as suggested by Berges (2008:30-43) with a good history of research or as a continuation of the Jeremiah scroll, according to Steck (1992:197-198) and Kratz (1994:259). These views are, in my opinion, preferable to the traditional idea Kratz (1994:259). These views are, in my opinion, preferable to the traditional idea
that Deutero-Isaiah was conceived from the very beginning as a supplement to that Deutero-Isaiah was conceived from the very beginnin
Proto-Isaiah; see amongst many others Williamson (1994). redactor, also claims that Yhwh's anger does not last for a long time, but that this time of wrath has definitely come to an end:

For a brief moment I abandoned you, but with great compassion I will gather you. In overflowing wrath for a moment I hid my face from you, but with everlasting love I will have compassion on you, says Yhwh, your Redeemer. (Is 54:7-8) ${ }^{5}$

Interestingly, the attitude of the author(s) of Isaiah 40-55 is to take over the official rhetoric of the Cyrus cylinder (see Table 1) and to proclaim the Persian ruler, by doing so, to be Yhwh's messiah for Israel and the world.

Second Isaiah presents Yhwh in the same role that the Babylonian god, Marduk, plays in the Cyrus cylinder. In both cases, the patron deity of a defeated city is said to have chosen the victorious king to inaugurate a new era of salvation. Does Second Isaiah therefore betray a monotheistic ideology? In any case, Isaiah 40-55 shows a tendency to transfer to Yhwh aspects and functions that in polytheistic religions are assumed by different divine figures.

\section{Yhwh as a goddess in the book of Second Isaiah}

As already mentioned, the different groups that edited the traditions of the Pentateuch and the prophetic books in the Persian era were hostile to the traditional concept of a divine couple. The somewhat strange vision in Zechariah 5:5-11 may reflect this hostility. The prophet sees a woman, called

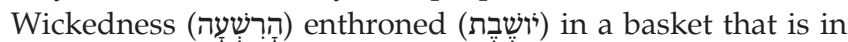
turn transported by two winged women to Shinar (Babylon) where a house or temple (בְּית) is built for her in which she will stand on a support (מכונָָ). Several commentators (Uehlinger 1994; Edelman 2003) have argued with good reason that this vision reflects the expelling of the goddess from Jerusalem to a 'pagan' nation, and this may well be the case. Perhaps

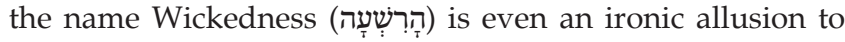
Asherah (אָשֵׁרָה). Even if the matter is still disputed by some scholars (Lemaire 1984), there is sufficient biblical (1 Ki 15:13; 16:33; 2 Ki 13:6; 21:3 \& 7; 23:6-7) and extra-biblical (Kuntillet Ajrud; Khirbet el-Qom) evidence for the fact that Asherah was worshipped in Israel and Judah as Yhwh's paredra (Hadley 1994; Na'aman \& Lissovsky 2008; Olyan 1988). The argument that in some biblical passages Asherah means a religious symbol (e.g. 1 Ki 14:23; 2 Ki 17:10; 18:4), a sacred tree and not the goddess, does not meet the point, since the symbols of a deity are always 'images' or representations of that deity.

The book of Second Isaiah, as well as some other texts from the Persian period, reveals a strategy to overcome the vanishing of Yhwh's 'wife', Asherah. Second Isaiah claims frequently that Yhwh is god, or ' $\mathrm{El}^{\prime}$ ', and there is no one else besides him. ${ }^{6}$ The claim to exclusivity raises the question about the management of roles traditionally attributed to

5.Many authors limit the first version of Second Isaiah to Isaiah the original passages included in 40-52; see the overview in Leuenberger (2010:50).

6.See Isaiah 46:9: 'Remember the former things from the beginnings (ראשנוּת מעוֹוֹסים)',

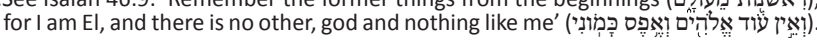


TABLE 1: Cyrus Cylinder and Second Isaiah.

\section{Cyrus Cylinder}

$12 \mathrm{He}$ (Marduk) took the hand of Cyrus...

and called him by his name

$13 \mathrm{He}$ made the land of Guti and all the Median troops prostrate themselves at his feet

while he shepherded in justice and righteousness the black-headed people

15 like a friend and companion, he (Marduk) walked at his side.

$32 \mathrm{I}$ collected together all of their people and returned them to their settlements.

Second Isaiah

45:1 Cyrus, whose right hand I took

$45: 3$ I, Yhwh, the God of Israel, call you by your name.

$45: 1$ to subdue nations before him

44:28 who says of Cyrus, 'He is my Shepherd',

$45: 2$ I will walk before you

45:13 I have aroused Cyrus ... and I will make all his paths straight; he shall build my city and set my exiles free.

$\dagger$, Translation according to Finkel, I. n.d., 'Translation of the Cyrus Cylinder', viewed 10 October 2012, from http://www.britishmuseum.org/explore/highlights/article_index/c/cyrus_cylinder_-translation.aspx

goddesses. The solution in Second Isaiah (and in some other texts from the same period) is to transfer the competences of the goddess to Yhwh (Briend 1992:74-76). A number of texts compare Yhwh to a mother, like Isaiah 49:15: 'Can a woman forget her nursing-child, or show no compassion for the child of her womb? Even these may forget, yet I will not forget you.' A maternal metaphor also occurs in Isaiah 46:3: 'Listen to me, O house of Jacob, all the remnant of the house of Israel, who have been born by me from your birth, carried from the womb.' Isaiah 42:14 even goes further by presenting Yhwh as woman in pains who gives birth to Israel, his child: 'Like a woman in labour I groan, I will gasp and pant.' In this passage, the return from exile is compared to a rebirth of Israel, and Yhwh resembles here a mother goddess. However, in the preceding verse (v. 13), Yhwh is depicted as a warrior, preparing for battle against his enemies. Isaiah 42:13-14 apparently tries to combine, in regard to Yhwh, the attributes of a warrior god and a mother goddess. Something similar happens in the late psalm of Deuteronomy 32, where Yhwh is presented at the same time as father and mother of Israel. In verse 6, Yhwh is called 'father', and in verse 18 he is said to be 'the rock who fathered you and the God (El) who

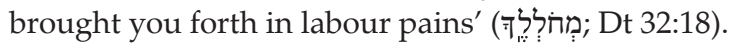

In the last chapter of the book of Hosea, which was reworked in the Persian period or even originated in that time (Nissinen 1991), Yhwh also takes over the attributes of Asherah, since he is compared to an evergreen cypress tree that provides fertility to Israel (Wacker 1994). Perhaps one may follow the ingenious emendation of Julius Wellhausen, according to which the second part of Hosea 14:9, quite obscure in

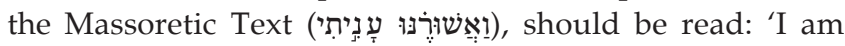
your Asherah and your Anat' (Wellhausen 1963:134) - an emendation that makes perfectly sense, especially since the popularity of Anat is well attested in the documents from the Jewish community in Elephantine.

In the book of Hosea, as well as in Jeremiah and Ezekiel, another transformation can be observed. Now Israel becomes Yhwh's adulteress wife, who is punished because she constantly is looking for other lovers, that is, foreign gods (Jr 2; Ezk 16, 23). In Hosea 1-3, the marriage of the prophet with a prostitute symbolises Yhwh's relation with Israel. Hosea 1-3, which older scholarship has attributed to the oldest layers of the books, is now considered by many scholars as a prologue that was added, at earliest, in the time of the Babylonian exile, or during the early Persian period (see for instance Wacker 1996 and Kratz 2003:63).
During the Persian period, there were apparently attempts to integrate aspects of the goddesses into Yhwh, but these attempts were restricted to a small corpus of texts. The exclusivist Yhwh remained male. The goddesses were therefore transformed into new 'partners' of Yhwh.

\section{The new 'wives' of Yhwh}

One way to present Yhwh as a husband after the disappearance of the goddess, is the transfer of the divine couple to the couple, Yhwh-Israel, especially in prophetic texts. Israel plays here the role of Yhwh's adulteress wife, who leaves him for other gods and who is therefore repudiated, and eventually rehabilitated (Wacker 1996). In some of these prophetic texts, Yhwh is even bigamous since he is married to Israel and Judah, or to Samaria and Jerusalem (Jr 3; Ezk 16, 23).

Another evolution is the personification of 'wisdom' in the first chapters of the book of Proverbs. In Proverbs 8, Hokmah presents herself in the same way as does Yhwh (and the

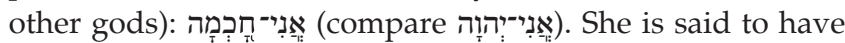

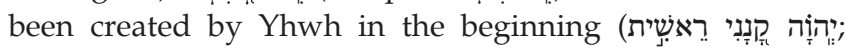
$\operatorname{Pr} 8: 22)$, but she precedes the creation of the world; she is even presented as Yhwh's craftswoman. This is a possible translation of Proverbs 8:30: 'I was beside him as a craftsman'

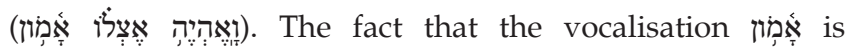
unusual $^{7}$ and that the word is masculine has led to variants in manuscripts and translations, like 'little child' or 'constantly'. ${ }^{8}$ But the idea of a goddess who assists the creator God, makes sense and reminds of the Egyptian couple Ra and Maat. Hokma is also presenting herself as 'delighting

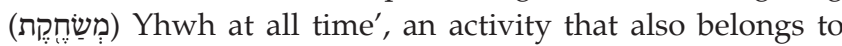
the duty of a wife towards her husband. That means that Proverbs 8 re-associates a feminine figure with Yhwh (Schroer 1991). Speculatively, one may also ask whether this association explains the plural that the creator God is using in Genesis 1:26: 'Let us make humankind (אָָדָ) in our image.' This humankind is then created male and female (Gn 1:27), which suggests in a way that the image reflects a male and a female god.

\section{Yhwh, creator of 'good and evil'}

In polytheistic systems, the existence of misfortune and evil is not problematic. There are always demons, or chthonic

7.It should read אמן; the vocalisation of the Massoretic Text corresponds to the name of a Judean king Amon, who might relate to the Egyptian deity.

8.Absolute infinitive; for a discussion of the variants, see Gorges-Braunwarth (2002:242-249) 
deities, or other frightening gods that are responsible for bad things affecting human beings. The problem arises in a one-god centred system. This can be observed in the Biblical version of the flood story. In the Mesopotamian accounts, there are two different types of gods: those who decide to exterminate humankind, and the friendly god who warns the future survivor. In Genesis 6-9, however, Yhwh has to play both parts: he decides to destroy all creatures and he alerts Noah in order to make mankind and animals to survive.

Second Isaiah also asserts that Yhwh is responsible for the good and the evil:

I am Yhwh, and there is no other; besides me no god. I arm you, though you do not know me, so that they may know, from the rising of the sun and from the west, that there is no one besides me; I am Yhwh, and there is no other. I form light (יוֹצור אור (ילור) and

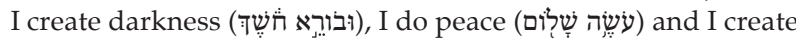

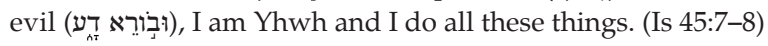

This oracle is linked with the institution of Cyrus as Yhwh's messiah through whom he will make known to the whole world that he is the 'only' god. There is some discussion

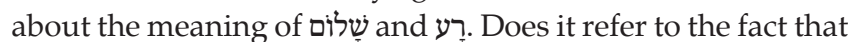
Yhwh is responsible, not only for peace, but also for war and defeats (Berges 2008:404-406)? This would be a continuation of a kind of Deuteronomistic ideology, according to which Yhwh provokes cataclysms in order to punish his people. The mention of Cyrus, who is presented as the tool through which Yhwh will bring peace and restoration to Israel, would indeed fit with such a historical understanding of $r a^{\prime}$ and shalom. On the other hand, the parallel with the creation of 'light' and 'darkness' suggests a more general meaning: Yhwh is responsible also for the evil, or chaos, in the world. 'Shalom' would then mean something like the Egyptian $m a^{\prime}$ at (the order of the world) and $r a^{\prime}$, the chaos. The Isaiah manuscript from Qumran (1QIs ${ }^{a}$ ) replaced shalom by tob, making Yhwh the creator of good and evil. A similar affirmation also occurs in the prologue to Job, where Job responds to his wife: 'Should we receive what is good (הטובובים) from the deity (הָאלדזים), and not also receive what is evil (הזרע)?' (Job 2:10). ${ }^{9}$ Isaiah 45:5-7 and Job 2 would then reflect an attempt to make Yhwh also responsible for the chaos and the evil. If it is true that Second Isaiah depicts Yhwh as the only god by taking over discourses about other gods, especially Marduk, then one may ask if the emphasis on the creation of evil can also be understood, at least partially, as a reaction to Persian dualism, according to which Ahura-mazda is 'only' the god of 'good'. ${ }^{10}$ Be it as it may, the attempt to integrate the 'evil' into Yhwh remained, however, somewhat marginal.

\section{The autonomy of chaos or evil in writings from the Persian period}

According to some scholars, like Albani (2000:239-241) and Leuenberger (2010:70-71), the root ברא is a theological invention of Second Isaiah, who needed a specific verb for the divine creation. In this case, one has to understand the 9.See also Lamentations 3:38

10.See, however, the critical statement of Berges (2008:406). priestly creation account in Genesis 1 as a polemical reaction to Isaiah 45. According to $\mathrm{P}$, when God creates heaven and earth, he begins with the creation of light, but the darkness exists already and is, contrary to Isaiah 45, not created (Gn 1:1-3). According to Genesis 1, the creator God does not create everything: darkness and the primordial waters (תוֹה are integrated into the created world. Creation is here a transformation of a chaotic situation into an organised universe, but still represents, at least virtually, a threat to the ordered world. This may also be the case at the end of the priestly flood account, where God places his bow in the clouds. The divine arc can be understood as representing the ongoing fight of the creator God against the aquatic monster, symbol of chaos (Zenger 1983).

Another strategy to maintain chaos or evil outside Yhwh, is the invention of the figure of Satan ${ }^{11}$. Into the prologue of the book of Job, the scenes where satan ('the adversary') appears are clearly inserted into an existing story. The following arguments confirm this idea. Firstly, 'satan' only appears in chapter 1 and not at the end of the prose narration. Secondly, in the present text there is a grammatical inconsistency. Job 1:12-13 reads:

[12] Yhwh said to the Satan, 'Very well, all that he has is in your power; only do not stretch out your hand against him!' So the Satan went out from the presence of Yhwh. [13] One day when his sons and daughters were eating and drinking wine in the eldest brother's house ...

According to the present context, the personal pronoun 'his' would refer to the Satan or Yhwh, which of course makes no sense. The reference is to verse 6 where Job is mentioned for the last time, so that in the original text verse 6 was followed immediately by verse 13:

[6] And when the feast days had run their course, Job would send and sanctify them, and he would rise early in the morning and offer burnt-offerings according to the number of them all; for Job said, 'It may be that my children have sinned, and cursed God in their hearts'. This is what Job always did. [13] One day when his sons and daughters were eating and drinking wine in the eldest brother's house ... (Job 1:6, 13)

The encounter between Yhwh and the Satan has been inserted into this original context. The original story did not know about a satan. It depicted an arbitrary god, who without evident reason plagues a pious man. The expression 'אש אלהּי in Job 1:16 also suggests that the calamities were sent by God and not by a Satan, and Job's answer, that one must accept good and evil from God, confirms the idea of the original story.

For a later redactor, this view was unacceptable. Therefore he reintroduced into the story the traditional concept of a heavenly court in which Yhwh is surrounded by his 'sons'

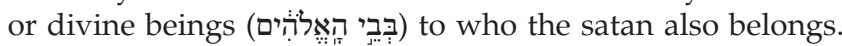
For sure, he is not put on the same level as Yhwh. The term is not used as a proper name - it designates the function of a secret agent of a sort and he cannot act without Yhwh's permission. However, we have here an attempt to extract the evil from Yhwh.

11.Note that in the prologue of Job, 'satan' is not a proper name, but a noun meaning 'the adversary'. 
The same holds true for the rewriting of 2 Samuel 24 in the book of Chronicles. According to 2 Samuel 24:1, Yhwh himself manipulated David to undertake a census, for which he is then heavily punished: 'Again the anger of Yhwh was kindled against Israel, and he incited David against them, saying, "Go, count the people of Israel and Judah"'. In the parallel account in 1 Chronicles 21, the narrative starts in the following way: 'Satan stood up against Israel, and incited David to count the people of Israel.' For the Chronicler, the story as presented in the book of Samuel was untenable, and he altered his Vorlage by introducing Satan who replaces the anger of Yhwh and is therefore responsible for the evil that happens to David (Knoppers 2004:751).

These texts from the Persian period (or even Hellenistic period for the book of Chronicles) demonstrate a tendency to create a figure representing evil that is separated from Yhwh. Some centuries later, this tendency will develop in some circles into a dualistic worldview, which is not the case in the Hebrew Bible.

\section{Conclusion}

In the early Persian period, Second Isaiah elaborated a discourse that presented Yhwh as the only god. Therefore, he had to integrate into this deity functions traditionally attributed to goddesses and to demons or evil gods. However, this attempt did not succeed. The goddess returned in a certain way through the personification of Wisdom in Proverbs 8 , and the 'dark sides' of the gods were materialised in the figure of Satan, who experienced an impressive career in the following centuries.

This evolution makes it difficult to characterise the Hebrew Bible as the result of a straightforward evolution from polytheism to monotheism. The sovereign god Yhwh could not really integrate the feminine and the evil for good and all.

\section{Acknowledgements Competing interests}

The author declares that he has no financial or personal relationship(s) that may have inappropriately influenced him in writing this article.

\section{References}

Ackerman, S., 1989, “'And the women knead dough": The worship of the Queen of Heaven in sixth-century Judah', in P.L. Day (ed.), Gender and difference in Ancient Israel, pp. 109-124, Fortress Press, Minneapolis. PMid:2549268

Ahn, G., 1993, 'Monotheismus - Polytheismus. Grenzen und Möglichkeiten eine Klassifikation von Gottesvorstellungen', in M. Dietrich \& O. Loretz (eds.) Mesopotamia - Ugaritica - Biblica (Festschrift Kurt Bergerhof), pp. 1-24, Neukirchener Verlag, Neukirchen-Vluyn. (AOAT 232).

Albani, M., 2000, Der eine Gott und die himmlischen Heerscharen: zur Begründung des Monotheismus bei Deuterojesaja im Horizont des Astralisierung des Gottesverständnisses im Alten Orien, Evangelische Verlagsanstalt, Leipzig.

Berges, U., 2008, Jesaja 40-48, Herder, Freiburg, Basel/Wien.

Briend, J., 1992, Dieu dans l'Ecriture, Cerf, Paris.

Edelman, D., 2003, 'Proving Yahweh killed his wife (Zechariah 5:5-11)', Biblical Interpretation 11, 335-344. http://dx.doi.org/10.1163/156851503322566769
Finkel, I. n.d., 'Translation of the Cyrus Cylinder', viewed 10 October 2012, from http:// www.britishmuseum.org/explore/highlights/article_index/c/cyrus_cylinder_translation.aspx

Gorges-Braunwarth, S., 2002, 'Frauenbilder - Weisheitsbilder - Gottesbilder' in Spr 1-9: Die personnifizierte Weisheit im Gottesbild der nachexilischen Zeit, Lit-Verlag, Münster.

Hadley, J.M., 1994, 'Yahweh and "his Ashera": Archeological and textual evidence for the cult of the goddess', in M. Dietrich \& M.A. Klopfenstein (eds.), Ein Gott allein ? JHWH-Verehrung und biblischer Monotheismus im Kontext der israelitischen und altorientalischen Religionsgeschichte, pp. 235-268, Universitätsverlag, Vandenhoeck \& Ruprecht, Freiburg/Göttingen.

Knoppers, G.N., 2004, 1 Chronicles 10-29, Doubleday, New York.

Koch, K., 1988, 'Aschera als Himmelskönigin in Jerusalem', Ugarit-Forschungen 20, 97-120.

Köckert, M., 2009, 'Vom Kultbild Jahwes zum Bilderverbot. Oder: Vom Nutzen der Religionsgeschichte für die Theologie', Zeitschrift für Theologie und Kirche 106, 371-406. http://dx.doi.org/10.1628/004435409789877960

Kratz, R.G., 1994, 'Der Anfang des Zweiten Jesaja in Jes 40,1f. und das Jeremiabuch', ZAW 1994, 243-261.

Kratz, R.G., 2003, Die Propheten Israels, C.H. Beck, München. (Beck'sche Reihe 2326). Lemaire, A., 1984, 'Who or what was Yahweh's Aschera?', BAR 10(6), 42-51.

Le Roux, J., 2008, 'Suffering and hope during the Exile', in B. Becking \& D. Human (eds.), Exile and suffering. A selection of papers read at the 50th anniversary meeting of the Old Testament Society of South Africa, OTWSA/OTSSA, Pretoria, South Africa, August, 2007, pp. 19-32.

Le Roux, J., 2009, 'Searching for a question and an answer', in R. Achenbach \& M. Arneth (eds.), 'Gerechtigkeit und Recht zu üben' (Gen 18,19). Studien zur altorientalischen und biblischen Rechtsgeschichste, zur Religionsgeschichte Israels und zur Religionssoziologie. Festschrift für Eckart Otto zum 65. Geburtstag, pp. 508-517, Harrassowitz, Wiesbaden.

Leuenberger, M., 2010, 'Ich bin Jhwh und keiner sonst': der exklusive Monotheismus des Kyros-Orakels Jes. 45, 1-7, Verlag Katholisches Bibelwerk, Stuttgart.

MacDonald, N., 2003, Deuteronomy and the meaning of 'monotheism', Mohr Siebeck, Tübingen.

Niehr, H., 1997, 'In search of YHWH's cult statue in the First Temple', in K. van der Toorn (ed.), The Image and the Book. Iconic cults, aniconism, and the rise of the book religion in Israel and the Ancient Near East, pp. 73-95, Peeters, Leuven.

Na'aman, N. \& Lissovsky, N., 2008, 'Kuntillet Ajrud, Sacred Trees and the Asherah', Tel Aviv 35, 186-208.

Nissinen, M., 1991, Prophetie, Redaktion und Fortschreibung im Hoseabuch: Studien zum Werdegang eines Prophetenbuches im Lichte von Hos 4 und 11, Butzon \& Bercke/Neukirchener Verlag, Kevelaer/Neukirchen Vluyn.

Olyan, S.M., 1988, Ashera and the cult of Yahweh in Israel, Scholars Press, Atlanta.

Pritchard, J.B. (ed.), 1955, Ancient Near Eastern Texts Relating to the Old Testament, 2nd edn., Princeton University Press, New Jersey.

Römer, T., 2009, 'Le dossier biblique sur la statue de Yhwh dans le premier temple de Jérusalem. Enquêtes scripturaires à travers la Bible hébraïque', Revue de Théologie et de Philosophie 141, 321-342.

Römer, T., 2010, 'Les monothéismes en question', in T. Römer (ed.), Enquête sur le Dieu unique, pp. 7-17, Bayard, Paris.

Schmitz, P.C., 1992, 'Queen of Heaven', in D.N Freedman (ed.), Anchor Bible Dictionary, pp. 586-588, vol. V, Yale University Press, New Haven.

Schroer, S., 1991, 'Die göttliche Weisheit und der nachexilische Monotheismus', in $\mathrm{M}$-T. Wacker \& E. Zenger (eds.), Der eine Gott und die Göttin. Gottesvorstellungen des biblischen Israel im Horizont feministischer Theologie, pp. 151-182, Herder, Freiburg.

Steck, O.H., 1992, Gottesknecht und Zion. Gesammelte Aufsätze zu Deuterojesaja, Mohr, Tübingen.

Stolz, F., 1996, Einführung in den biblischen Monotheismus, Wissenschaftliche Buchgesellschaft, Darmstadt.

Uehlinger, C., 1994, 'Die Frau im Efa (Sach 5,5-11). Eine Programmvision von der Abschiebung der Göttin', Bibel und Kirche 49, 93-103.

Uehlinger, C., 1995, 'Gibt es eine joschijanische Kultreform? Plädoyer für ein begründetes Minimum', in W. Groß (ed.), Jeremia und die "deuteronomistische Bewegung, pp. 57-90, Beltz Athenäum, Weinheim.

Wacker, M-T., 1994, 'Spuren der Göttin im Hoseabuch', in W. Dietrich \& M.A. Klopfenstein (eds.), Ein Gott allein? JHWH-Verehrung und biblischer Monotheismus im Kontext der israelitischen und altorientalischen Religionsgeschichte, pp. 329348, Universitätsverlag/Vandenhoeck \& Ruprecht, Freiburg/Göttingen.

Wacker, M-T., 1996, Figurationen des Weiblichen im Hosea-Buch, Herder/Freiburg, Basel/Wien

Williamson, H.G.M., 1994, The book called Isaiah. Deutero-Isaiah's role in composition and redaction, Oxford University Press, Oxford. http://dx.doi. org/10.1093/0198263600.001.0001

Wellhausen, J., 1963, Die Kleinen Propheten. Skizzen und Vorarbeiten, reprint of 3rd edn. (1889), Töpelmann, Berlin.

Zenger, E., 1983, Gottes Bogen in den Wolken: Untersuchungen zu Komposition und Theologie der priesterschriftlichen Urgeschichte, Katholisches Bibelwerk, Stuttgart. 